\title{
NADGOPLAŃSKI GRÓD SZARLEJ I JEGO WLAŚCICIELE W ŚREDNIOWIECZU
}

\author{
SZARLEJ: A GORD AT LAKE GOPŁO AND ITS MEDIEVAL OWNERS
}

\begin{abstract}
The gord of Szarlej is located on a small peninsula on the south-western coast of Lake Szarlej at the mouth of the river Noteć. Gopło - a ribbon lake - reached that far in the late Middle Ages. The gord of Szarlej was established in the last decade of the first half of the $14^{\text {th }}$ century on the initiative of Kazimierz Ziemomysłowic, a Kuyavian prince and the lord of Gniewkowo, or alternatively by his son and successor, Władysław the White. The gord in Szarlej was built following destruction of the previous ducal residence in Gniewkowo during an invasion of the Teutonic Knights in 1332. The stronghold was a favourite residence of Władysław the White, prince of Gniewkowo until 1363 when he placed a lien against it to Kazimierz the Great, king of Poland. Most probably, after 1382 another ruler of Kuyavia, prince Vladislav II of Opole, handed over the stronghold in Szarlej to the affluent Kuyavian Ostoja family. The first nobility owner of the Szarlej estate (encompassing the stronghold, the villages, Łojewo, Witowy and Karczyn), confirmed in the sources, was Mikołaj of Ściborze $(\uparrow 1457)$. He was a member of the political elite of late-medieval Kuyavia.
\end{abstract}

Keywords: Kuyavia, gords, Gopło, Mikołaj Szarlejski, Jan Kościelecki.

Średniowieczny gród Szarlej położony był na niewielkim półwyspie w południowej części zachodniego brzegu dzisiejszego Jeziora Szarlejskiego, które jeszcze w późnym średniowieczu stanowiło część Gopła. Według Chorografii Jana Długosza pobudowano go w miejscu, gdzie jezioro Gopło „koło zamku Szarlej wypuszcza z siebie niemałą rzeczkę, zwaną Noteć, z jego wnętrza wypływającą" (Długosz 1962, s. 140). Dziś grodzisko, wyróżniające się bardzo dobrze zachowaną formą terenową, należy administracyjnie do osady Ostrowo Krzyckie (ryc. 1).

Pierwszy szarlejskie grodzisko szerzej opisał w formie gazetowego szkicu Wincenty Hipolit Gawarecki (1839, s. 379-380). Jednak późniejsze dziesięciolecia

* ORCID 0000-0002-2422-1962; Uniwersytet Zielonogórski, Instytut Historii, al. Wojska Polskiego 69, 65-762 Zielona Góra, e-mail: J.Karczewska@ih.uz.zgora.pl; https://orcid.org.

** ORCID 0000-0002-2701-7887; Uniwersytet Kazimierza Wielkiego w Bydgoszczy, Wydział Historyczny, ul. Księcia Józefa Poniatowskiego 12, 85-671 Bydgoszcz, e-mail: karian@ukw.edu.pl. 
wzbudziły tylko niewielkie nim zainteresowanie ze strony historyków i archeologów, co zapewne wynika $\mathrm{z}$ odosobnionego położenia na poligonie wojskowym 2. Pułku Inżynieryjnego im. gen. Jakuba Jasińskiego w Inowrocławiu. Wcześniejsze badania, nieliczne i najczęściej tylko powierzchniowe, szczegółowo podsumowali Witold Hensel i Zofia Hilczer-Kurnatowska (Hensel i Hilczer-Kurnatowska 1987, s. 329). Latem 2020 roku szerzej niż dotychczas badania terenu dawnego grodu (Ostrowo Krzyckie, st. 1) przeprowadziła ekipa z Instytutu Archeologii UMK w Toruniu. Chociaż wyniki ich prac nie zostały jeszcze opublikowane, można już stwierdzić, że zlokalizowano tam relikty zabudowy z trzech okresów. Z wczesnego średniowiecza - gród z fazy przedpaństwowej, na którym powstał późnośredniowieczny gród w formie kopca obwiedzionego podwójnym systemem fos i wału pierścieniowatego pomiędzy fosami (ryc. 2A). W okresie wczesnonowożytnym zaś postawiono na nim murowany dwór obronny (Błędowski, Bojarski, Chudziak, Freygant-Dzieruk i Kaźmierczak 2020). W połowie XVI wieku fortalicja połączona była ze wschodnim brzegiem Jeziora Szarlejskiego drewnianym mostem, usytuowanym nieco na północ od grodziska. Jego fragmenty poddane datowaniu metodą dendrochronologiczną wskazują, że użyte do jego budowy bale dębowe pochodzą z lat 1530-1550 (Chudziak, Kaźmierczak i Niegowski 2016, s. 209-212). O nich zaś wspomniał Józef Kościelski, ówczesny właściciel tej wsi, w swych młodzieńczych Sonetach nadgoplańskich. Pozostałości mostu miały wystawać na „stope prawie” (około $31 \mathrm{~cm}$ ) ponad poziom wody (Kościelski 1868, s. 32). Był to efekt obniżenia poziomu jeziora Gopło o prawie 1,4 m po melioryzacji gruntów przeprowadzonej w latach 1856-1859 w obrębie zlewni górnej Noteci i Bachorzy (Schulemann 1861, s. 52-65; Dorożyński i Skowron 2002, s. 94-95). W tym czasie nastąpiło również ostateczne przerwanie łączności Jeziora Szarlejskiego z Gopłem i powstanie pomiędzy nimi pasa mokradeł, ciągnącego się na długości około $3 \mathrm{~km}$ wzdłuż nurtu Noteci. W wyniku późniejszych prac nad regulacją Noteci w ostatniej ćwierci XIX wieku poziom wód Gopła ustabilizował się na mniej więcej 77 m n.p.m. (Niewiarowski 2000, s. 193; Dorożyński i Skowron 2002, s. 94). Odzwierciedla on też współczesny poziom Jeziora Szarlejskiego, lecz uświadamia, że gdy opisywany gród budowano w połowie XIV wieku, poziom lustra wody w Gople oscylował wokół swej maksymalnej wartości około 80 m n.p.m. (Dzieduszycki 1984, s. 181). Tym samym można przyjąć, że w późnym średniowieczu gród położony był na terenie zalewowym lub stanowił wyspę, a obie fosy były stale wypełnione wodą (ryc. 2B, 2C). Budowa warowni w Szarleju przypadła już na sam schyłek epoki grodów obronnych. Tak też było na Kujawach i ziemi dobrzyńskiej, gdzie na terenie byłego już księstwa gniewkowskiego król Kazimierz Wielki (zm. 1370) wystawił murowany zamek w Złotorii, w newralgicznym miejscu u ujścia Drwęcy do Wisły, tuż przy granicy ziemi dobrzyńskiej z państwem Zakonu Krzyżackiego w Prusach (Kajzer i Horonziak 1995, s. 85-86, 214-217).

Szarlej był jednym z częstszych miejsc pobytu księcia gniewkowskiego Władysława Białego. Świadczą o tym stosunkowo liczne dokumenty wystawione przez 


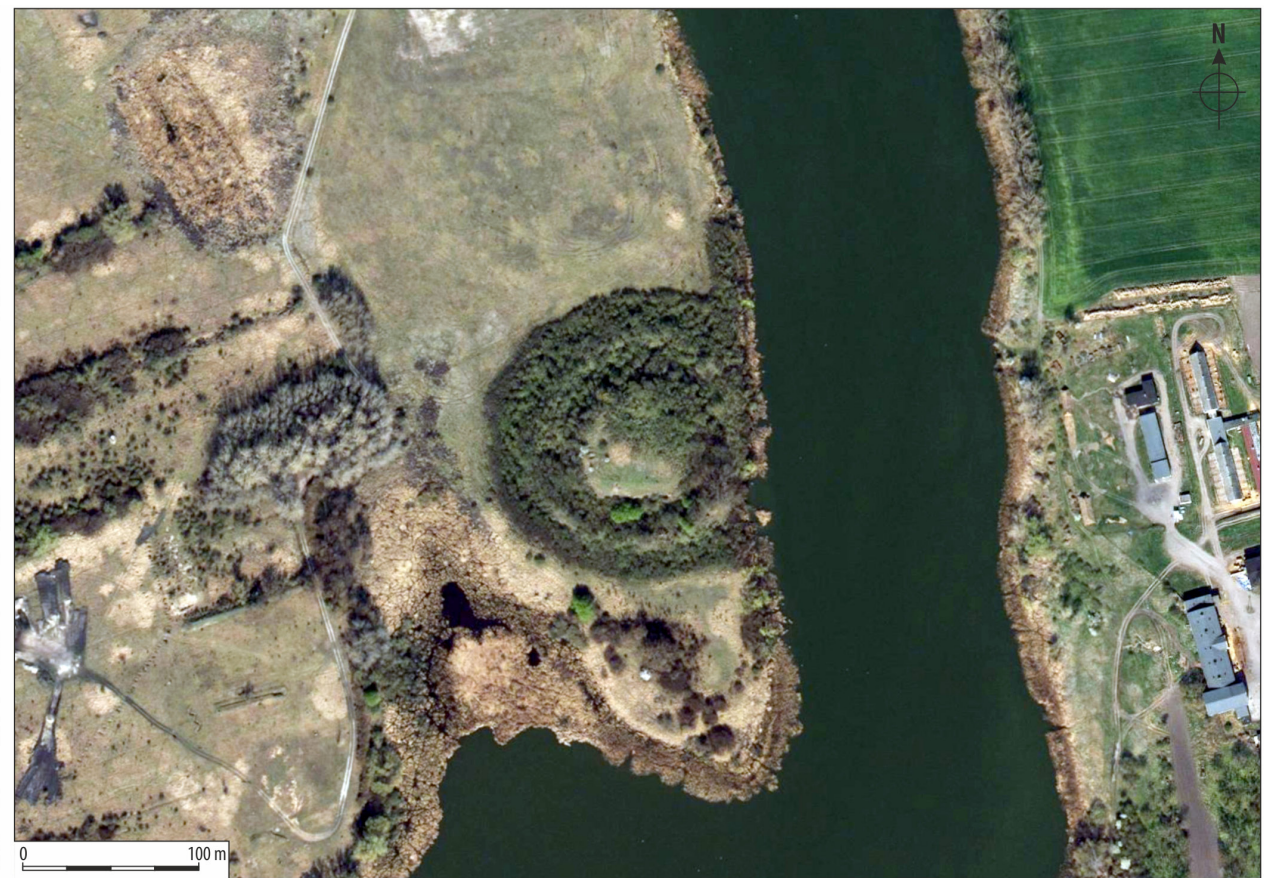

Ryc. 1. Grodzisko Szarlej w Ostrowie Krzyckim - położenie na tle współczesnego ukształtowania terenu. Ortofotomapa z serwisu mapy.geoportal.gov.pl

niego w tym grodzie w latach 1353-1363 ${ }^{1}$. Jego ojciec - Kazimierz Ziemomysłowic - zmarł przed 13 maja 1350 roku, jest to zarazem terminus ante quem objęcia samodzielnych rządów przez Władysława Białego (Jasiński 1993, s. 8-9; Jasiński 2001, s. 186). Można przyjąć, że budowa grodu w Szarleju była następstwem zniszczenia dotychczasowej rezydencji książęcej w Gniewkowie w czasie najazdu krzyżackiego w 1332 roku. Przypuszczamy, że prace budowlane mogły nastąpić, począwszy od 1343 roku, gdyż w tym roku Kazimierz Ziemomysłowic powrócił do swojego księstwa z kilkuletniego wygnania (Bieniak 1974, s. 90-92). Gród szarlejski strzegł południowo-zachodniej rubieży księstwa gniewkowskiego (Kabaciński 1974, s. 18, 22), wątpliwe jednak, aby kiedykolwiek funkcjonowała ,ziemia szarlejska" jako teren okręgu grodowego (tak przyjmują Guldon i Powierski 1974, s. 90-91, 93). Trzeba tu również zwrócić uwagę, że przy rekonstrukcji granic księstwa gniewkowskiego zawsze brano pod uwagą tylko osadę Szarlej i Jezioro

1 KDP 1848, nr 297 (1353: in Szarlej); Śliwiński J. 2011, s. 116-117, dodatek źródłowy nr II (1354: Sarley); KDP 1847, nr 120 (1355: in Szarley); Guldon i Kabaciński 1974, s. 12-14, nr $4=$ Śliwiński J. 2011, s. 115-116, dodatek źródłowy nr I (1362: in castro Sarley); KDP 1852, nr 516 (1363: in castro nostro Sarley); 517 (1363: in Garle castro). Najprawdopodobniej również KDP 1847, nr 124 (1362). 

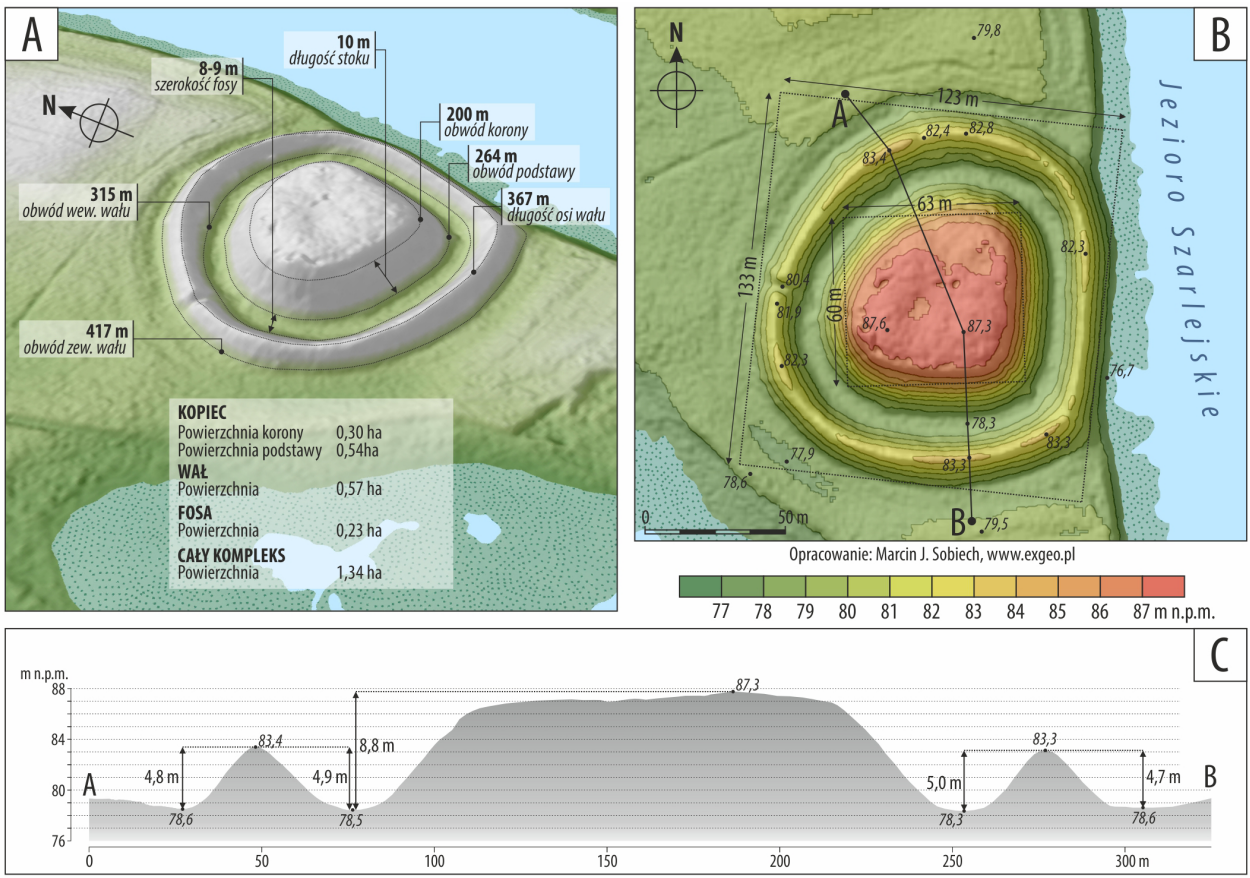

Ryc. 2. A - Model grodziska Szarlej w Ostrowie Krzyckim na podstawie danych z lotniczego skaningu laserowego (LiDAR - ALS). Wymiary zostały obliczone na podstawie obrysów form wyznaczonych przebiegiem izohips: 85 m n.p.m. (obwód korony kopca) i 79 m n.p.m. (obwód podstawy kopca, obwód wewnętrzny i zewnętrzny wału). B - Plan hipsometryczny grodziska Szarlej w Ostrowie Krzyckim z naniesionymi maksymalnymi wymiarami zewnętrznymi budowli. C - Profil hipsometryczny grodziska Szarlej w Ostrowie Krzyckim

Szarlejskie. Tymczasem położenie grodu wskazuje, że tereny leżące na zachodnim brzegu jeziora wraz z całym jego akwenem także należy zaliczyć do terytorium gniewkowskiego. W połowie XV wieku nadnoteckie łąki należące do Inowrocławia dochodziły do granic Szarleja, co mogło być śladem wcześniejszych delimitacji dzielnicowych (KDP 1852, nr 592; Karczewski 2000-2001, s. 67-71).

Nigdy jednak gród szarlejski nie odegrał znaczniejszej roli politycznej i militarnej, tym bardziej że w 1363 roku Władysław Biały zostawił swe księstwo Kazimierzowi Wielkiemu i wyruszył do Ziemi Świętej, aby później osiąść w klasztorze, najpierw u cystersów w Cîteaux, ostatecznie zaś u benedyktynów w Dijon (Śliwiński 2011, s. 38-54). Ostatni raz Szarlej ponownie znalazł się na kartach historii we wrześniu 1373 roku, kiedy książę Władysław Biały podjął swoją pierwszą wyprawę na Kujawy w celu odzyskania ojcowizny. Bez oporu podporządkowali mu się mieszczanie Inowrocławia (wraz z zamkiem) i rodzinnego Gniewkowa, bez walki zajął również zamek w Złotorii. Natomiast 10 września 
1373 roku książę Władysław obległ castrum inexpugnabile (zamek niezdobyty) Szarlej, którego obrońcy, po znikomym oporze, poddali się mu już nazajutrz (11 września 1373). Jednak wobec swojego trudnego położenia politycznego, zimą 1373-1374 książę zgodził się oddać tę twierdzę Sędziwojowi z Szubina, staroście generalnemu Wielkopolski z ramienia króla Ludwika Węgierskiego (Jan z Czarnkowa 1872, s. 655-656; Śliwiński J. 2011, s. 80-84). Od tego momentu przez dłuższy czas brak wiadomości źródłowych o tej warowni. Odosobniona wzmianka pochodzi z końca września 1409 roku, gdy król Władysław Jagiełło wraz ze swoją armią rozłożył się obozem na polach pod zamkiem Szarlej (Długosz 1997, s. 32; Gąsiorowski 2015, s. 67). Najprawdopodobniej był on wtedy już własnością prywatną. U schyłku średniowiecza we wsi był folwark, sześć karczem (tabern) oraz sześciu osiadłych kmieci, którzy pro fortalicio pertinentes. Jako zagrodnicy siedzieli oni na półłankach wydzielonych z gruntów folwarcznych (Senkowski 1961, s. 168).

$* * *$

Król Węgier i Polski Ludwik Andegaweński w 1378 roku w zamian za Ruś nadał księciu Władysławowi Opolczykowi następujące terytoria: ziemię dobrzyńską, ziemię wyszogrodzką (bydgoską) z Bydgoszczą, Tuczno, Inowrocław, Gniewkowo oraz zamki Złotoria i Szarlej (KDW 1982, nr 259: ... et castra, videlicet Slothoria et Scharley). Książę opolski otrzymał więc we władanie teren północnych Kujaw, jednak w 1378 roku nie objął tego terytorium, ponieważ ciążył na nim sedes viduali Małgorzaty Siemowitówny, wdowy po księciu Kaźku Słupskim. Jej prawa zostały uznane i zastawiono jej ziemię dobrzyńską na sumę jej posagu, tj. ośmiu tysięcy grzywien (Jan z Czarnkowa 1872, s. 680). Księżna jednak nie chciała ustąpić z ziemi dobrzyńskiej, w związku z czym książę Władysław Opolczyk objął władzę nad nadanymi mu terytoriami dopiero na przełomie 1379 i 1380 roku (KDP 1852, nr 530). Dopiero od 1380 roku Władysław Opolczyk sprawował władzę nad północnymi Kujawami, z tego bowiem czasu pochodzą dokumenty, które tego dowodzą - 28 marca 1380 roku książę wystawił dokument dla mieszczan inowrocławskich, używając w nim tytulatury kujawskiej, w kolejnych dyplomach, tym razem z 3 kwietnia 1380 i 7 kwietnia 1380 roku jest wzmiankowany tylko z tytułem dobrzyńskim (DKM 1887, s. 257-268 nr 89; CDPr. 1848, nr 142; Guldon i Powierski 1974, s. 220-221). Nadanie Kujaw inowrocławskich i ziemi dobrzyńskiej, które Opolczyk otrzymał w 1378 roku, zostało potwierdzone przez króla 17 kwietnia 1382 roku (KDW 1982, nr 276). Wydaje się, że jest to terminus post quem przejścia Szarleja w ręce prywatne, czyli na własność rodziny herbu Ostoja, używającej przydomka Mościc i dziedziczącej w Ściborzu (na północ od Inowrocławia). Wydarzenie to wiążemy właśnie z okresem rządów na północnych Kujawach i w ziemi dobrzyńskiej księcia Władysława Opolczyka. Nie był on szczególnie związany z tym terytorium i dokonywał na nim różnych zapisów i transakcji, 
w tym przede wszystkim zastawu na rzecz Krzyżaków Złotorii 5 maja 1391 roku i ziemi dobrzyńskiej 28 lipca 1392 roku (KDP 1852, nr 542, 544). Mógł on pozbyć się Szarleja z zamkiem na rzecz miejscowych rycerzy i jednocześnie swoich urzędników bez szczególnego żalu. Książę ten notorycznie bywał zadłużony, co tylko wzmacnia przypuszczenie, że Szarlej stał się obiektem jakiejś transakcji handlowej - sprzedaży lub zastawu, lecz chyba nie było to nadanie. Książę, mający problemy finansowe, raczej niechętnie dokonywałby nadań dóbr. Przypuszczalnie Ostojowie stali się właścicielami Szarleja przed 13 maja 1390 roku. Wtedy bowiem Opolczyk nadał swej córce Jadwidze i jej mężowi księciu kiernowskiemu Wiguntowi-Aleksandrowi, jako opiekunowi i gubernatorowi, ziemie inowrocławską, tuczeńską i bydgoską (KDP 1852, nr 538). Raczej wątpliwe jest, aby przejście Szarleja w ręce Ostojów nastąpiło w czasie rządów Władysława Jagiełły, ten władca bowiem wówczas jeszcze nie szafował hojnymi nadaniami.

W połowie XIV wieku najwybitniejszym przedstawicielem rodu Ostojów był Mościc ze Ściborza, którego imię stało się drugą nazwą rodu (Szymański 1993, s. 215). Był on wojewodą gniewkowskim (inowrocławskim) w latach 1353-1375, zmarł przed 1383 rokiem (Szybkowski 2006, s. 654). Trudno jednak stwierdzić jednoznacznie, czy już on stał się właścicielem Szarleja, czy zmiana własnościowa nastąpiła w następnym pokoleniu tej rodziny. Pierwszymi źródłowo potwierdzonymi posiadaczami Szarleja pochodzącymi z rodu Ostojów byli bowiem wnukowie Mościca - Mikołaj ze Ściborza i jego brat Ścibor ze Ściborza na początku XV wieku (KSB-K 1905, nr 1141, 1253, 1572, 1603, 2929). Byli oni synami Mikołaja Mościcowica zwanego Purcz, który był kasztelanem bydgoskim potwierdzonym na tym urzędzie między 26 marca 1382 a 9 grudnia 1399 roku (Urzędnicy 2014, s. 76, $\mathrm{nr} 171)^{2}$. O ich pochodzeniu od Mikołaja Purcza wnioskujemy z zapiski sądu brzeskiego z 9 stycznia 1402 roku, sąd przełożył wówczas sprawę synów „pani bydgoskiej" - a więc Mikołajowej małżonki kasztelanowej bydgoskiej Krzemki. Owi synowie to Mikołaj i Ścibor, ich adwersarzem był krewny matki Jan z Żydowa, a sprawa dotyczyła dóbr macierzystych ${ }^{3}$.

Kwestię własności w Szarleju i jej rozmiar oświetla późny, bo wystawiony 10 maja 1493 roku pozew królewski skierowany do Mikołaja Kościeleckiego, syna Jana z Kościelca (zm. 1474), który przejął dobra po zmarłym Mikołaju Szarlejskim, wojewodzie brzeskim w latach 1452-1457, jednym ze wspomnianych wyżej synów Mikołaja Purcza. Pozywającą była Barbara Chraplewska, wdowa z Rudnic, nazwana w dokumencie stryjeczną siostrzenicą Mikołaja Szarlejskiego, która swe roszczenia uzasadniała prawem bliższości po swej babce a stryjecznej siostrze Szarlejskiego - Grzymce Łabiskiej (z Łabiszynka koło Gniezna). Osobom występującym w tej sprawie poświęci się uwagę niżej, tu natomiast zajmiemy się głównie kwestią majątku wymienionego w pozwie. Przedmiotem pozwu były dobra po

${ }^{2}$ Mikołaj Purcz był także starostą inowrocławskim w 1389 roku (Urzędnicy 2014, s. 141, nr 482).

${ }^{3}$ Archiwum Główne Akt Dawnych w Warszawie, Brześć Z. 2, k. 54v. 
zmarłym bezpotomnie Mikołaju Szarlejskim (...absque prole mortui bone memorie), choć jest prawdopodobne, że posiadał on potomstwo naturalne (o czym niżej). Jako jego dziedziczne dobra ojczyste (bona hereditaria paterna) zostały wymienione: Szarlej z warownią, Łojewo, Witowy, Karczyn i Ściborze (villam Sharley cum fortalicio et villas Loyewo, Vythowo, Kaczyno, Sczyborze) (Szybkowski 2003a, s. 227). Oprócz Ściborza, które było dawną rodową siedzibą Ostojów, został wymieniony Szarlej z kluczem dóbr, w którego skład wchodziły trzy wsie. Literatura podawała ich nazwy w brzmieniu Łojewo, Witowo, Kaczkowo (Szyb-

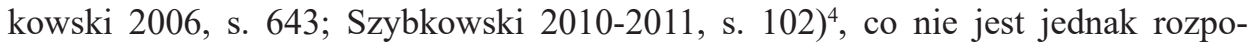
znaniem poprawnym. Łojewo wymienione w pozwie to właściwie Łojewko, tak brzmiała nazwa tej wsi w XV wieku, w takiej formie wymienia ją lustracja poradlnego z 1489 roku (Senkowski 1961, s. 168). Z czasem Łojewko zostało włączone w obręb Szarleja (Guldon 1964, s. 96). Część Łojewa jeszcze w 1354 roku została sprzedana przez księcia Władysława Białego klasztorowi Norbertanek ze Strzelna (Śliwiński J. 2011, s. 116-117, dodatek źródłowy nr II). Następnie w pozwie chodzi o Witowy - wieś w pobliżu Szarleja, należącą do tej samej parafii w Górze; nazwa w takim brzmieniu jest wymieniona w lustracji poradlnego w 1489 roku (Senkowski 1961, s. 168). Nie chodzi tu o Witowo - wieś o tej nazwie leżała w powiecie radziejowskim. Natomiast źródłowe „Kaczyno” to Karczyn w parafii górskiej, leżący niedaleko Szarleja. Identyfikacja tej wsi z Kaczkowem - wsi w parafii Płonkowo - łatwo się narzucała, leży bowiem ona bardzo blisko rodowego Ściborza. Jednak w XV wieku w Kaczkowie dziedziczyli Łabędzie i Pomianowie (Szybkowski 2006, s. 706). Wątpliwości co do identyfikacji wsi wchodzących w skład klucza szarlejskiego rozwiewają dotyczące ich XVI-wieczne wpisy do ksiąg sądowych, z których wyraźnie wynika, że chodzi o Witowy i Karczyn w parafii Góra w powiecie inowrocławskim, chociaż okazjonalnie pisarze zapisywali nazwy tych wsi w brzmieniu „Witowo” i „Karczino” 5 .

Szarlej z zamkiem i pobliskimi trzema wsiami tworzył zwarty kompleks majątkowy, położony w obrębie jednej parafii w pobliskiej Górze (Senkowski 1961, s. 168). W związku z tym, że znajdowało się tam wzmiankowane fortalicium, był on ośrodkiem rezydencjonalnym, który dał nazwisko wojewodzie brzeskiemu Mikołajowi, jakkolwiek pisał się on także z patrymonialnego Ściborza. Cytowany wyżej pozew z 1493 roku określa wszystkie wymienione wsie Szarlejskiego jako dobra dziedziczne ojczyste. Wyjaśnia zatem, że Szarlej z kluczem dóbr znajdował się już w rękach ojca Mikołaja Szarlejskiego - czyli kasztelana bydgoskiego Mikołaja Purcza, nie wiadomo jednak, czy przejście Szarleja w ręce Ostojów nie

\footnotetext{
${ }^{4}$ Z kolei w pracy Szybkowski 2003a nazwy wszystkich tych wsi, poza Karczynem, zostały podane prawidłowo.

${ }^{5}$ http://teki.bkpan.poznan.pl/index_regesty.html (dostęp 21.02.2021): Grodzkie i ziemskie/ Poznań/ Inskrypcje/XVI w./część 2/7204 (Nr 897); Grodzkie i ziemskie/Pyzdry/część 1/5109, (Nr 179); Grodzkie i ziemskie/Nakło/część 1/1613 (Nr 155).
} 
nastąpiło wcześniej - w czasach wojewody gniewkowskiego Mościca. Wydaje się, że trzeba raczej osobno rozpatrywać dzierżenie przez Ostojów klucza szarlejskiego i sprawę posiadania przez nich Szarleja z zamkiem. Wiadomo, że Łojewko (Łojewo) było w XIII-XIV wieku własnością rycerską i znajdowało się w posiadaniu rodu Łabędziów (Bieniak 1987, s. 28; Śliwiński B. 1993, s. 46-48) ${ }^{6}$. Z tego czasu znani są dziedzice z Łojewka - Jarosław, w latach 1282-1292 wojewoda inowrocławski (Śliwiński B. 1993, s. 46-48; Karczewska 1997, s. 133-134; Urzędnicy 2014, s. 110, nr 327)7, Włodzimierz z Łojewa ${ }^{8}$ i Stanisław z Łojewa (Śliwiński J. 2011, s. 116-117, dodatek źródłowy nr II). Z drugiej połowy XIV wieku brak informacji źródłowych o dziedzicach Łojewka, pochodzą one dopiero z czasów Mikołaja Szarlejskiego. Możliwe, że Ostojowie kupili Łojewko i pozostałe dwie wsie właśnie od Łabędziów. Nie można też wykluczyć innej ewentualności - mianowicie małżeństwa dziedziczki - jedynaczki z rodu Łabędziów z Ostoją i przejścia majątku do rodu Ostojów. Łabędziowie posiadali majątki m.in. na terenie północnych Kujaw, gdzie są dość dobrze udokumentowani w XIII wieku (Śliwiński B. 1989, s. 57-59, 110-111). Zarówno Łabędzie, jak i Ostojowie należeli do starej, miejscowej elity. Ich dobra sąsiadowały ze sobą, były bowiem skupione w północnej części Kujaw inowrocławskich. Domniemane małżeństwo między Łabędziówną a Ostoją mogło być zawarte w połowie XIV wieku, i niewykluczone, że zawarł je wojewoda Mościc. Jednakże nie byłoby to jego jedyne małżeństwo, interesujące nas wsie z klucza szarlejskiego były bowiem później w posiadaniu tylko potomków Mikołaja Purcza i jego nieznanego z imienia brata, którego córką była wspomniana wcześniej Grzymka Łabiska - stryjeczna siostra Mikołaja Szarlejskiego. Jako dobra macierzyste nie mogły więc wchodzić w skład majątku innych synów wojewody gniewkowskiego Mościca i rzeczywiście nie ma na ten temat wzmianek źródłowych. Natomiast sam Szarlej z zamkiem znalazł się w posiadaniu Ostojów, jak to wyżej przedstawiono, prawdopodobnie po 1382 roku.

Pierwszymi źródłowo potwierdzonymi szlacheckimi właścicielami Szarleja byli synowie kasztelana bydgoskiego Mikołaja Purcza - Mikołaj i Ścibor ze Ściborza. Ich matką była Krzemka z Łowiczka z rodu Łabędziów. Obaj bracia, określeni jako synowie „pani bydgoskiej”, zostali wymienieni w zapisce sądowej brzeskiej 9 stycznia 1402 roku, kiedy to sąd brzeski odłożył ich sprawę z Janem z Żydowa

${ }^{6}$ Śliwiński B. (1993) opisuje także dość skomplikowane kwestie własnościowe w Łojewie - wieś musiała liczyć kilka działów, stanowiących własność rycerską i kościelną.

7 Karczewska (1997, s. 133-134) błędnie uznała go wówczas za Pomiana.

8 Archiwum Państwowe w Bydgoszczy, klasztor Cystersów w Koronowie, pow. Bydgoszcz, sygn. 6-437-52. 
(powiat brzeski) na osiem lat (Szybkowski 2003b, s. 170)9. Powodem takiego orzeczenia sądu z pewnością była niepełnoletność kasztelaniców. Mikołaj i Ścibor dziedziczyli w powiecie brzeskim dobra po matce (Redecz Krowi, Żydowo), i z tego tytułu niejednokrotnie występowali przed tamtejszym sądem, choć częściej stawiał się w nim Mikołaj, działając także w imieniu swego brata. Właśnie księgi sądowe brzeskie piszą Mikołaja z przydawką posesjonatywną „z Szarleja” (de Scharley) lub Szarlejskim, jak chociażby w 1419 roku w sprawie z Krzesławem z Dowieszyna (KSB-K 1905, nr 1141, 1253, 1603, 2131, 2136, 2253, 2293 i inne; KDW 1993, nr 1601). Mikołaj z Szarleja był najznaczniejszą osobistością związaną z XV-wiecznym Szarlejem.

Mikołaj i jego brat Ścibor należeli do kujawskiej rodziny urzędniczej, która szczególną pozycję osiągnęła w 2. połowie XIV i na przełomie XIV i XV wieku dzięki karierze stryja młodych kasztelaniców - Ścibora ze Ściborza. Warto nieco bliżej przedstawić tę postać, jej działalność i osiągnięcia oddziaływały bowiem na pozostałych krewniaków. Ścibor ze Ściborza zrobił wielką karierę na dworze króla Węgier Zygmunta Luksemburczyka (Prochaska 1912; Dvořákova 2003). Według opinii Stanisława A. Sroki, jej początków można doszukiwać się w związkach łączących Ostojów-Mościców z księciem Władysławem Opolczykiem, gdy ten rządził na Kujawach, a był, jak wiadomo, silnie związany z dworem Andegawenów węgierskich (Sroka 2001, s. 74). Z kolei S. Szybkowski wnioskuje, że pozycja Ścibora mogła wynikać wprost z przychylności króla Ludwika Andegaweńskiego, któremu Ostojowie-Mościcowie lojalnie i wiernie służyli (Szybkowski 2003, s. 161-162). Ścibor był ochmistrzem króla Zygmunta Luksemburskiego, wojewodą Rusi Czerwonej, osiągnął urząd wojewody siedmiogrodzkiego, stając się jednym z najpotężniejszych możnowładców na Węgrzech. Oprócz tych tytułów i zaszczytów zgromadził wiele majątków na terenie Górnych Węgier (zwłaszcza na Poważu). Zadbał także o karierę swych krewniaków i ich majątkowe uposażenie.

Mikołaj z Szarleja wprawdzie kariery na Węgrzech nie zrobił, lecz bywał tam kilkakrotnie - w 1435 roku, w latach 1439-1441 i w roku 1443. Jego stryjeczny brat, żyjący na Węgrzech syn palatyna siedmiogrodzkiego Ścibor młodszy, w swoim testamencie z 1431 roku postanowił, że w przypadku bezpotomnej śmierci jego jedynej córki Katarzyny, połowę dóbr węgierskich miał otrzymać właśnie Mikołaj zwany Mikołajkiem (Wenzel 1874, s. 190-198, nr 147; Gąsiorowski 1995, s. 492-503). Spadku po Ściborze Szarlejski jednak nie objął, choć próbował to uczynić zbrojnie; w 1435 roku został pozbawiony praw do tej schedy. W późniejszych latach Mikołaj otrzymał na Węgrzech zapisy na dobrach monarszych, obejmujące m.in. zamek Košeca - mogły one być rekompensatą za utracony spadek (Szybkowski 2010-2011, s. 98, 99).

Mikołaj Szarlejski osiągnął godności w kujawskich urzędniczych hierarchiach ziemskich oraz łaskę królewską za swe służby oddane królowi, co zaowocowało

\footnotetext{
9 Archiwum Główne Akt Dawnych w Warszawie, Brześć Z. 2, k. 54v.
} 
sutymi nadaniami w postaci starostw. Otrzymał lukratywne nadania, zwłaszcza na Kujawach, gdzie skupił w swym ręku starostwa brzeskie, inowrocławskie, bydgoskie (z Solcem i Gniewkowem), był również tenutariuszem kilku wsi w powiecie inowrocławskim i brzeskim, wykupił także starostwo kowalskie (Szybkowski 2010-2011, s. 98-99; KDP 1852, nr 394, 581; DKM 1887, s. 169-171, nr 98). O jego prestiżu może wymownie świadczyć, że miał grono swoich urzędników, określonych „nadwornymi” (curie nostre). Wśród nich w 1441 roku został wymieniony Stanisław z Maszenic, burgrabia w Szarleju (DKM 1887, s. 169-171, nr 98).

Pierwszym urzędem ziemskim w karierze Szarlejskiego było podstolstwo brzeskie, na którym był potwierdzony między 18 listopada 1435 a 15 grudnia 1436 roku (Urzędnicy 2014, s. 189, nr 61). Urząd ten mógł jednak objąć wcześniej, jego poprzednik ostatni bowiem raz w tej godności był wzmiankowany 6 lutego 1425 roku (Urzędnicy 2014, s. 189, nr 60). Z tego urzędu Mikołaj awansował na kasztelanię inowrocławską, na której przebywał między 26 listopada 1437 a 28 sierpnia 1451 roku (Urzędnicy 2014, s. 198, nr 120). Kolejnym urzędem w jego karierze była palacja brzeska. Urząd ten sprawował między 25 marca 1452 a 24 maja 1457 roku (Urzędnicy 2014, s. 192, nr 84); zmarł prawdopodobnie 23 czerwca 1457 roku (Liber mortuorum 1888, s. 742). Z cursus honorum Mikołaja Szarlejskiego wynika, że jego kariera przypadła na lata obfitujące w niezwykle brzemienne w skutki wydarzenia polityczne, zwłaszcza w stosunkach polsko-krzyżackich, Szarlejski zaś był aktywnym ich uczestnikiem, czego dowodem jest m.in. to, że był jednym z gwarantów pokoju brzeskiego z 1435 roku (Szybkowski 2003c, s. 98).

Szarlejski był liderem szlachty kujawskiej, a także przywódcą stronnictwa królewskiego na Kujawach. Bezkrólewie po śmierci Władysława Warneńczyka i objęcie tronu przez Kazimierza Jagiellończyka przyniosły zmiany na ziemi kujawskiej, które bezpośrednio dotknęły także Szarlejskiego. W latach 1445-1447 doszło do zbrojnych zamieszek na Kujawach, których powodem były między innymi zmiany na starostwach kujawskich, podjęte jeszcze za życia Władysława III. Szarlejski został wówczas pozbawiony starostwa inowrocławskiego i nieszawskiego, lecz w 1449 roku otrzymał tenutę krzepicką ${ }^{10}$. Rywalizował wówczas o utrzymanie pozycji i wpływy z nowym lokalnym konkurentem, którym był pochodzący z ziemi dobrzyńskiej Jan Kretkowski (Szybkowski 2018, s. 188). Mikołaj jednak swą pozycję utrzymał, a jej ukoronowaniem było osiągnięcie urzędu wojewody brzeskiego (przed 25 marca 1452); w międzyczasie zmarł też jego rywal Jan Kretkowski, co załagodziło konflikty na Kujawach. Szarlejski był nie tylko miejscowym liderem, lecz należał do grona wpływowych osobistości połowy XV wieku oddziałujących na politykę krajową. W szczególny sposób odzwierciedla to jego zaangażowanie w sprawy Związku Pruskiego i inkorporacji Prus w 1454 roku. Mikołaj już wcześniej uczestniczył w misjach dyplomatycznych do Krzyżaków, a jako kujawski terrigena był $\mathrm{w}$ sprawach pogranicza dobrze zorientowany (Szybkowski

${ }^{10} \mathrm{http} / /$ www.slownik.ihpan.edu.pl/search.php?id=8375\&q=krzepice\&d=3\&t=1 (dostęp 10.03.2021). 
2018, s. 193-194). Szarlejski, należący do tzw. stronnictwa Wielkopolan, popierał działania Związku Pruskiego i brał udział w realizacji polityki królewskiej względem pruskiej opozycji (Biskup 1959, s. 210-213; Fałkowski 1992, s. 26, 71-73). Był świadkiem aktu inkorporacji Prus do Królestwa Polskiego. Dowodził wojskami zaciężnymi i pospolitym ruszeniem Związku Pruskiego z części Pomorza, które zaczęły oblężenie Chojnic. Podczas działań militarnych pod Chojnicami Szarlejski był jednym z dowódców, a po klęsce poniesionej w tej bitwie dostał się do krzyżackiej niewoli, gdzie przebywał do kwietnia 1455 roku (Biskup 1965, s. 94). Po powrocie z niewoli, mimo niepowodzenia w bitwie chojnickiej, Mikołaj otrzymał tenutę tucholską, a także zamki Świecie i Osiek (MRSP 1905, nr 193; Karczewski 1994, s. 106). W tym czasie przebywał przy królu, czego świadectwem jest jego obecność w królewskich dokumentach. Należał do grona najwyższych dostojników Królestwa, brał więc udział w ważnych dla państwa wydarzeniach, a jako urzędnik ziemski uczestniczył też w partykularzu i posiedzeniach sądu ziemskiego.

Znaczącym gestem ze strony Szarlejskiego była jego rezygnacja na rzecz Jana Kościeleckiego 27 marca 1457 roku z posiadanych przez niego królewszczyzn, na które wtedy składały się: starostwo bydgoskie z Gniewkowem, starostwo tucholskie i cztery kujawskie wsie. Kościelecki przebywał w kręgu Szarlejskiego od lat, współpracował z nim, można się domyślać, że Szarlejski był dla niego mentorem i mieli dobre relacje. Brakuje informacji źródłowych o małżeństwie i legalnym potomstwie Mikołaja Szarlejskiego. Prawdopodobnie miał córkę naturalną, którą wydał za mąż właśnie za Jana Kościeleckiego, ewentualnie była ona jego bratanicą - córką naturalną jego brata Ścibora. Wraz z jej ręką Jan Kościelecki objął również majątek po Mikołaju Szarlejskim, w tym dobra szarlejskie (Szybkowski 2003 a, s. 125-129; Szybkowski 2018, s. 189, 408). Małżeństwo to musiało być postrzegane jako mezalians, a objęcie dóbr po Szarlejskim przez Jana Kościeleckiego spowodowało pozwy dalszych krewnych zmarłego Mikołaja. Kwestie związane z dziedziczeniem po nim dóbr przedstawił Sobiesław Szybkowski (2003a), a uściślił Bronisław Nowak (2009). Ostatni z wymienionych historyków przedstawił także nowe spojrzenie na sprawę związków krewniaczych łączących Szarlejskiego ze wspomnianą już wyżej Grzymką Łabiską i jej descendentami, którzy rościli sobie pretensje do schedy po Szarlejskim. Z zapisów w wielkopolskich księgach sądowych wynika, że niektórzy z nich posiadali część dóbr klucza szarlejskiego (Witowy) przed 1486 rokiem, a więc parę lat przed zbiorowym pozwem potomków Łabiskiej z 1493 roku. Do tych osób zaliczał się Michał Czestek z Gorynina herbu Poraj - syn Grzymki Łabiskiej, a potem jego synowie. Wynikałoby więc, że Kościeleccy rozliczyli się, przynajmniej częściowo, z krewniakami Szarlejskiego (Nowak 2009, s. 67, 69). Sprawa jednak była kontynuowana, jak wspomniano, w 1493 roku. Z notatek dotyczących jej przebiegu wiadomo, że w 1493 roku Mikołaj Kościelecki zapisał dług w wysokości czterech tysiący złotych księdzu Mikołajowi z Janczewa i jego bratu Maciejowi z Łabiszyna (tj. Łabiszynka), 
Mikołajowi, Jerzemu i Wawrzyńcowi - braciom z Kobielic, Wojciechowi i Maciejowi z Trąbczyna, Annie Owieczkowskiej i Barbarze Chrapiewskiej (Chraplewskiej) za ich prawo bliższości do Szarleja wraz z zamkiem po Mikołaju Szarlejskim, którego nazwano wtedy ich wujem, co było nieprawdziwym określeniem łączącego ich pokrewieństwa ${ }^{11}$. O spadek po Mikołaju Szarlejskim procesował się także Jan - syn Michała z Żelechlina koło Inowrocławia, kanonik przy kościele św. Marii Magdaleny w Poznaniu, który dowodził prawa bliższości do dóbr po wojewodzie Szarlejskim po swych pradziadach (Szybkowski, 2003, s. 179-180). Jednakże wiadomo, że w XVI wieku klucz szarlejski znajdował się w rękach Kościeleckich, dokonywali oni bowiem na tych dobrach różnych zapisów majątkowych ${ }^{12}$. W efekcie dobra te pozostały $\mathrm{w}$ rodzinie Kościeleckich i blisko spokrewnionej z nimi rodzinie Działyńskich herbu Ogończyk do początku XVIII wieku.

\section{BIBLIOGRAFIA}

Archiwum Główne Akt Dawnych w Warszawie, Brześć Z. 2.

Archiwum Państwowe w Bydgoszczy (dalej: APB), Klasztor Cystersów w Koronowie, pow. Bydgoszcz, sygn. 6-437-52.

http://teki.bkpan.poznan.pl/index_regesty.html (dostęp 21.02.2021).

Bieniak J. 1987, Ród Łabędziów, w: J. Hertel, J. Wroniszewski (red.), Genealogia. Studia nad wspólnotami krewniaczymi i terytorialnymi w Polsce średniowiecznej na tle porównawczym, Toruń, Wydawnictwo Uniwersytetu Mikołaja Kopernika, s. 9-31.

- 1974, Odzyskanie zachodnich Kujaw przez Kazimierza Wielkiego w 1337 r., „Zapiski Historyczne” 39, z. 3, s. 69-95.

Biskup M. 1959, Zjednoczenie Pomorza Wschodniego z Polska w połowie XV wieku, Warszawa, Państwowe Wydawnictwo Naukowe.

- 1965, Spisy jeńców polskich z bitwy pod Chojnicami, „Przegląd Historyczny” 56, s. 88-103.

Błędowski P., Bojarski J., Chudziak W., Freygant-Dzieruk M., Kaźmierczak R., 2020, Sprawozdanie $z$ opracowaniem wyników z badań archeologicznych o charakterze weryfikacyjno-sondażowym w Ostrowie Krzyckim, pow. Inowrocław, woj. kujawsko-pomorskie (stan. 1), mps, Toruń.

Chudziak W., Kaźmierczak R., Niegowski J. 2016, Podwodne dziedzictwo archeologiczne Polski. Katalog stanowisk (badania 2011-2015), Toruń, Wydawnictwo Uniwersytetu Mikołaja Kopernika.

CDPr. 1848, Codex diplomaticus Prussicus, Bd. 3, (hrsg.) von J. Voigt, Königsberg.

DKM 1887, Dokumenty kujawskie i mazowieckie przeważnie z XIII wieku, wyd. B. Ulanowski, Archiwum Komisji Historycznej Akademii Umiejętności, 4, Kraków.

Długosz J. 1962, Roczniki czyli Kroniki sławnego Królestwa Polskiego, ks. 1-2, J. Dąbrowski (red.), Warszawa, Państwowe Wydawnictwo Naukowe.

- 1997, Joannis Dlugossii Annales seu cronicae incliti Regni Poloniae, lib. X et XI, ed. consilium, Varsaviae, Wydawnictwo Naukowe PWN.

Dorożyński R., Skowron R. 2002, Changes of the basin of Lake Gopło caused by melioration work in the 18th and 19th centuries, "Limnological Review" 2, s. 93-102.

\footnotetext{
${ }^{11} \mathrm{http} / / /$ teki.bkpan.poznan.pl/index_regesty.html (dostęp 21.02.2021): Grodzkie i ziemskie/Poznań/ Rezygnacje/XV w./część 2/284 (23 zs).

${ }^{12} \mathrm{http}: / /$ teki.bkpan.poznan.pl/index_regesty.html (dostęp 21.02.2021): Grodzkie i ziemskie/Poznań/ Inskrypcje/XVI w./część 2/ 7204 (Nr 897); Grodzkie i ziemskie/Pyzdry/część 1/5109 (Nr 179); Grodzkie i ziemskie/Nakło/część 1/1613 (Nr 155).
} 
Dvořákova D. 2003, Rytier a jeho král'.Stibor zo Stiboric a Žigmund Lucemburský. Sonda do života stredovekého šl'achtica s osobitým zretel'om na územie Slovenska, Budmerice, Vydavatel'stvo Rak.

Dzieduszycki W. 1984, Wczesnośredniowieczna przeprawa przez Gopło (Z badań stanowiska 4 a w Kruszwicy), „Sprawozdania Archeologiczne” 36, s. 167-183.

Fałkowski W. 1992, Elita władzy w Polsce za panowania Kazimierza Jagiellończyka (1447-1492). Studium aspektów politycznych, Wydawnictwo Fundacji „Historia pro Futuro”, Warszawa.

Gawarecki W.H. 1839, Wiadomość o zamku Szarlej w Kujawach nad Goptem leżącym, „Magazyn Powszechny. Dziennik użytecznych wiadomości” 6, nr 48, s. 379-380.

Gąsiorowski A. 1995, Zygmunt Luksemburski i Sędziwój z Szubina, czyli o węgierskich apanażach rodziny Ścibora ze Ściborza, w: Cracovia-Polonia-Europa, Studia z dziejów średniowiecza ofiarowane Jerzemu Wyrozumskiemu w sześćdziesiąta piąta rocznice urodzin i czterdziestolecie pracy naukowej, Kraków, Wydawnictwo i Drukarnia „Secesja”, s. 493-503.

- 2015, Itinerarium króla Władysława Jagietly 1386-1434, wyd. 2, Warszawa, Instytut Historii PAN.

Guldon Z. 1964, Rozmieszczenie własności ziemskiej na Kujawach w II połowie XVI w., Toruń, Towarzystwo Naukowe w Toruniu.

Guldon Z., Kabaciński R. 1974, Inedita kujawskie i dobrzyńskie z lat 1345-1368, w: Dokumenty do dziejów Kujaw i ziemi dobrzyńskiej XIV-XIX w., Z. Guldon, R. Kabaciński, M. Kallas, J. Wojciak (wyd.), Warszawa-Poznań, Państwowe Wydawnictwo Naukowe, s. 3-17.

Guldon Z., Powierski J. 1974, Podziaty administracyjne Kujaw i ziemi dobrzyńskiej w XIII-XIV wieku, Warszawa-Poznań, Bydgoskie Towarzystwo Naukowe.

Hensel W., Hilczer-Kurnatowska Z. 1987, Studia i materiaty do osadnictwa Wielkopolski wczesnohistorycznej 6, Wrocław etc., Zakład Narodowy im. Ossolińskich.

Jan z Czarnkowa 1872, Kronika Jana z Czarnkowa, J. Szlachtowski (wyd.), w: Monumenta Poloniae Historica, 2, A. Bielowski (wyd.), Lwów, s. 601-756.

Jasiński K. 1993, Kazimierz - książe gniewkowski i jego rodzina, w: K. Jasiński, R. Kabaciński, Cz. Sikorski, Gniewkowo. Książęta - księstwo - miasto, Cz. Sikorski (red.), Gniewkowo, s. 5-17.

- 2001, Rodowód Piastów małopolskich i kujawskich, Poznań-Wrocław, Wydawnictwo Historyczne.

Kabaciński R. 1974, Terytorium księstwa gniewkowskiego w XIV wieku, „Ziemia Kujawska” 4, s. 15-30.

Kajzer L., Horonziak A. 1995, Budownictwo obronne ziemi dobrzyńskiej, Włocławek.

Karczewska J. 1997, Urzędnicy książą kujawskich Leszka, Przemysła i Kazimierza Ziemomysłowiców, cz. 1, „Ziemia Kujawska” 12, s. 101-137.

Karczewski D. 1994, Szarlejski Mikołaj, w: E. Mikołajczak (red.), Inowrocławski Stownik Biograficzny, t. 2, Inowrocław, Kujawsko-Pomorskie Towarzystwo Kulturalne, s. 106-107.

- 2000-2001, W 550. Rocznicę odnowienia przywileju lokacyjnego miasta Inowrocławia, ,Ziemia Kujawska" 14, s. 63-73.

KDP 1847, Kodeks dyplomatyczny Polski, 1, L. Rzyszczewski, A. Muczkowski, A.Z. Helcel (wyd.), Warszawa.

- 1848, Kodeks dyplomatyczny Polski, L. Rzyszczewski, A. Muczkowski (wyd.), 2, cz. 1, Warszawa.

- 1852, Kodeks dyplomatyczny Polski, L. Rzyszczewski, A. Muczkowski (wyd.), 2, cz. 2, Warszawa.

- KDW 1982, Kodeks dyplomatyczny Wielkopolski, 6, wyd. A. Gąsiorowski, H. Kowalewicz, Warszawa-Poznań, Państwowe Wydawnictwo Naukowe.

- 1993, Kodeks dyplomatyczny Wielkopolski 10, A. Gąsiorowski, T. Jasiński (wyd.), Warszawa-Poznań, Wydawnictwo Poznańskiego Towarzystwa Przyjaciół Nauk.

Kościelski J. 1868, Sonety nadgoplańskie, Poznań.

KSB-K 1905, Księgi sądowe brzesko-kujawskie 1418-1424, J.K. Kochanowski (wyd.) (Teki Pawińskiego, t. 7), Warszawa.

Liber mortuorum 1888, Liber mortuorum monasterii Strzelnensis ordinis Praemonstratensis, W. Kętrzyński (wyd.), w: Monumenta Poloniae Historica 5, Lwów, s. 719-767.

MRPS 1905, Matricularum Regni Poloniae summaria 1, T. Wierzbowski (wyd.), Warszawa.

Niewiarowski W. 2000, Uwagi o wahaniach poziomu wody w jeziorze Gopło: stanowisko 3 - Kruszwica (gm. Kruszwica), w: P. Molewski, W. Wysota (red.), Dawne i współczesne systemy morfogenetyczne środkowej części Polski Pótnocnej, Toruń, s. 189-194. 
Nowak B. 2009, Wielkopolscy spadkobiercy Mościców ze Ściborza, w: D. Karczewski (red.), Z dziejów pogranicza kujawsko-wielkopolskiego. Zbiór studiów 2, Strzelno, s. 53-82.

Prochaska A. 1912, Ścibor ze Ściborzyc, Roczniki Towarzystwa Naukowego w Toruniu 19, s. 137-208.

Schulemann A. 1861, Darstellung der Goplo-Bachorze-Montwey-Melioration in historischer, technischer und ökonomischer Beziehung, Berlin.

Senkowski J. 1961, Lustracja poradlnego i rejestr łanów województwa brzesko-kujawskiego i inowroctawskiego z r. 1489, „Teki Archiwalne” 7, s. 69-214.

Sroka S.A. 2001, Polacy na Węgrzech za panowania Zygmunta Luksemburskiego 1387-1437, Kraków, Towarzystwo Naukowe „Societas Vistulana”.

Urzędnicy 2014, Urzędnicy kujawscy i dobrzyńscy XII-XV wieku. Spisy, J. Bieniak, S. Szybkowski (opr.), A. Gąsiorowski (red.), Kórnik, Biblioteka Kórnicka Polskiej Akademii Nauk.

Szymański J. 1993, Herbarz średniowiecznego rycerstwa polskiego, Warszawa, Wydawnictwo Naukowe PWN.

Szybkowski S. 2003a, Studia z genealogii i prozopografii polskiej szlachty późnośredniowiecznej, Gdańsk, Wydawnictwo Uniwersytetu Gdańskiego.

- 2003b, Ostojowie (Mościce) ze Ściborza i inni Polacy na Węgrzech w późnym średniowieczu. Uwagi genealogiczne i prozopograficzne do prac Stanisława A. Sroki, „Klio. Czasopismo Poświęcone Dziejom Polski i Powszechnym" 3, s. 159-203.

- 2003c, Nowe źródła do dziejów polsko-krzyżackich rokowań w Brześciu Kujawskim w grudniu 1435 r., „Ziemia Kujawska” 16, s. 79-102.

- 2006, Kujawska szlachta urzędnicza w późnym średniowieczu (1370-1501), Gdańsk, Wydawnictwo Uniwersytetu Gdańskiego.

- 2010-2011, Szarlejski Mikołaj, w: Polski Stownik Biograficzny 47, Kraków, Polska Akademia Nauk, s. $98-103$.

- 2018, Kościeleccy ze Skępego herbu Ogon i ich protoplaści, Gdańsk, Wydawnictwo Uniwersytetu Gdańskiego.

Śliwiński B. 1989, Pogranicze kujawsko-pomorskie w XII-XIII wieku. Z dziejów Bydgoskiego i Wyszogrodzkiego w latach (1113-1296), Warszawa-Poznań, Państwowe Wydawnictwo Naukowe.

- 1993, Rozwój własności rycerskiej w poludniowej części Kujaw Inowrocławskich w XII i XIII wieku, „Ziemia Kujawska” 9, s. 45-76.

Śliwiński J. 2011, Władystaw Biały (1327/1333-20 luty 1388). Ostatni ksiązę kujawski. Największy podróżnik spośród Piastów, wyd. 2, Kraków, Wydawnictwo AVALON.

Wenzel G. 1874, Stibor vajda. Eletrajzi tanulmany, Budapest.

http://www.slownik.ihpan.edu.pl/search.php?id=8375\&q=krzepice\&d=3\&t=1 (dostęp 10.03.2021) 